\title{
NEM CSAK A JÓ PAP TANUL HOLTIG...
}

\author{
Pénzes Ferenc ${ }^{96}$
}

Az oktatás, képzés, tanulás kifejezések korábban hagyományosan a gyermek- és ifjúkorhoz kötödtek. Az élet minden területén tapasztalható, egyre gyorsabb ütemü változások azonban nem teszik lehetôvé, hogy a felnöttkorba lépett nemzedék abbahagyja a tanulást, és csak az élete elsö szakaszában megszerzett ismeretekre hagyatkozzon. A 21. század rengeteg kihívást tartogat minden ember számára, ezért nagyon fontos, hogy mindenki nemtöl, kortól és foglakozástól függetlenül meg tudja valósitani az egész életen át tartó tanulás stratégiáját. Egyre szélesebb réteg ismeri fel, hogy a gyorsan változó világban a sikeres szerepvállalásnak döntö feltétele a lifelonglearning folyamatában való részvétel, hiszen segitségével olyan új kompetenciákat és készségeket sajátithatunk el, amelyek nélkülözhetetlenek életünkhöz. Napjainkban már elmondhatjuk, hogy oktatási intézményekben, vállalkozásokban és számos kulturális intézményben foglalkoznak felnöttek képzésével, biztositanak lehetöséget az önmegvalósitásra, önképzésre. Az alábbiakban a felnőttoktatás és felnőttképzés néhány aspektusáról készitettünk pillanatfelvételt mind az Európai Unió, mind pedig Magyarország tekintetében.

A felnőttkori oktatással, képzéssel kapcsolatos terület még nem rendelkezik letisztult, egyértelmü fogalomrendszerrel. A különféle dokumentumokban alapvetően két kifejezés használatos. Afelnöttoktatás és a felnöttképzés fogalma széles értelemben a nagykorúságot elért személyek képzését jelenti. A felnöttoktatás fogalma a jogszabályokban az iskolarendszerü oktatással kapcsolatban jelenik meg, és ebben az értelemben azt a képzést jelöli, amelynek során a tanuló munkahelyi, családi vagy más irányú elfoglaltságához, a meglévő ismereteihez és életkorához igazodó iskolai oktatásban vesz részt. Az ilyen oktatás nappali, esti, levelező vagy más, sajátos munkarend szerint is szervezhető.

A felnöttképzés fogalma a felnőttképzési törvényben ${ }^{97}$ található meg, amelyben azt az iskolarendszeren kívüli képzésekre használják. Lényeges jellemzője, hogy a képzés résztvevői nem tanulói vagy hallgatói jogviszonyban állnak a képző intézménnyel. A felnőttképzésben olyan személy vehet részt, aki tankötelezettségét teljesítette, de tanköteles személy tankötelezettségének teljesítése mellett is bekapcsolódhat a felnőttképzésbe. Felnőttképzést nagyon sokféle típusú szervezet nyújthat: jogi személyek, jogi személyiség nélküli gazdasági társaságok, egyéni cégek, egyéni vállalkozók, illetve a nemzeti köznevelésről szóló állami intézményfenntartó központ által fenntartott köznevelési intézmények is.

A felnőttoktatás és felnőttképzés területével a nemzetközi irodalomban az - a már említett egész életen át tartó tanulás keretén belül foglalkoznak. Az Európai Bizottság 2011. évi Makinga European Area of LifelongLearning a Reality címü dokumentumában ${ }^{98}$ a témához kapcsolódó számos meghatározás mellett az egész életen át tartó tanulás definíciója is megtalálható. E szerint az egész életen át tartó tanulásba „,beletartozik minden olyan, az ember élete során végzett tanulási tevékenység, amelynek célja a tudás, a készségek és kompetenciák fejlesztése személyes, polgári, társadalmi és munkavállalási perspektívából". A dokumentum az oktatási és képzési programokat formális (iskolarendszerü formában folyó, elismert kimeneti képesítéssel záruló), nem formális (az iskolarendszerü intézmények mellett,

\footnotetext{
${ }^{96}$ Pénzes Ferenc, egyetemi adjunktus, DE-ÁJK

${ }^{97}$ 2013. évi LXXVII. törvény a felnőttképzésröl

98 http://eur-lex.europa.eu/LexUriServ/LexUriServ.do?uri=COM:2001:0678:FIN:EN:PDF (letöltés: 2015. november 27.)
} 
de strukturált formában folyó) és informális (a munkával, családdal pihenéssel kapcsolatos tevékenységek során nem szándékolt módon zajló) tanulási tevékenységekre osztotta fel. ${ }^{99}$

\section{Az uniós stratégiák és célkitüzések}

A számos állásfoglalás közül, amelyek az elmúlt évtizedekben jelentek meg, kiemelkedik az Európai Unió 2000-ben közzétett lisszaboni stratégiája az egész életen át tartó tanulásról. A dokumentumot 2000 márciusában a Lisszabonban ülésező európai állam- és kormányfők fogadták el Lisszaboni stratégia címen, amely fö céljaként azt tüzte ki, hogy „Európa 2010-re a világ legdinamikusabban fejlődő tudásalapú gazdaságává váljon, mely képes a fenntartható fejlődésre, több és jobb munkahely és nagyobb társadalmi kohézió megteremtésére." A dokumentum 28 fö célkitüzést és 120 köztes célt határozott meg. Köztük az egyik fó cél az oktatáshoz és képzéshez, ezen belül is kifejezetten a felnőttek képzéséhez kapcsolódott. Ezt jelzi, hogy a stratégiában több célkitüzést is megfogalmaztak ezzel kapcsolatban. Így például: - minden esetben jelentősen növekedjen az egy före jutó humán tőkébe történő beruházás;

- 2010-re feleződjön meg a 18-24 éves népességben azok aránya, akik nem szereztek felsőközépfokú végzettséget (azaz akik Magyarországon legfeljebb általános iskolai végzettséggel rendelkeznek), és nem tanulnak tovább;

- európai szinten határozzák meg a kulcskompetenciákat, amelyek a legfontosabbak a munkavállalás és a mindennapi élet során.

A Lisszaboni stratégia 2020-ig szóló folytatását, az Európa 2020 stratégiai programot 2010 tavaszán fogadta el az Európai Bizottság. E szerint a gazdasági növekedés három olyan alappillérre épül, amelyek egymással szoros kapcsolatban állnak, és egymást kölcsönösen erösítik:

- intelligens növekedés: a tudásra és az innovációra épülő gazdaság kialakítása;

- fenntartható növekedés: az erőforrásokkal hatékonyabban élő, környezetbarát és versenyképesebb gazdaság létrehozása;

- inkluziv növekedés: magas foglalkoztatási szinttel, valamint szociális és területi kohézióval jellemezhető gazdaság ösztönzése.

Az Európa 2020 programhoz öt nagy területen tartozik fö célkitüzés: foglalkoztatás, kutatásfejlesztés,környezetvédelem, oktatás és megfelelö iskolai végzettség és szegénységi küszöb. Az oktatáshoz, iskolai végzettséghez kapcsolódóan a dokumentum két mutatót emelt ki:

- a leszakadók (korai iskolaelhagyók) arányának a 2007. évi 15-ről 10\%-ra való csökkentése, - 2020-ig a felsőfokú végzettséggel rendelkezők arányának 31-ről legalább 40\%-ra növelése a 30-34 éves korosztály körében. Magyarország számára ettől eltérően 30,3\%-os célt határoztak meg, amelyet 2012-ben már megközelített, elérve a 29,9\%-os arányt.

Az oktatással kapcsolatos elemek elsősorban az intelligens növekedés stratégiájában jelennek meg. Az oktatás, képzés és egész életen át tartó tanulás területén Európának a diákok tanulási készségén (Európában negyedük gyenge olvasási készséggel rendelkezik), a korai iskolaelhagyók arányán (hétből egy fiatal korán kimarad az oktatásból és a képzésből) kell javítania. A képzések szerkezete nem minden esetben megfelelö, ezt jelzi, hogy ugyan a tanulók mintegy fele végez középfokon, ez azonban gyakran nem egyezik a munkaerőpiac szükségleteivel. A 25-34 éves fiatalok 31\%-ának van felsőfokú végzettsége, s ez az arány más fejlett országokban (Egyesült Államok, Japán) 40\%, vagy afölött van.

A stratégiához kiemelt kezdeményezések is kapcsolódnak, ezek közül a Mozgásban az ifjúság ${ }^{100}$ függ szorosan össze az oktatással. A kezdeményezés célja, hogy növelje a

\footnotetext{
${ }^{99}$ Vö. FARKAS Éva: A lifelonglearning mobilitási eszközök alkalmazási gyakorlata Magyarországon. SZTE JGYPK. Szeged, 2013. 9-13.

${ }^{100} \mathrm{http}: / /$ eur-lex.europa.eu/legal-content/HU/TXT/PDF/?uri=CELEX:52010DC0477\&from=HU letöltés: 2015. november 27.)
} 
felsőoktatási intézmények teljesítményét, uniós szinten javítsa az oktatás, képzés minőségét, és ezzel növelje a fiatalok foglalkoztatási esélyeit.

\section{Mi a helyzet itthon?}

Magyarországon a rendszerváltás után a felnőttoktatással foglalkozó intézmények állami támogatása látványosan csökkent, és sok esetben kizárólag a piacról kellett megélniük, ugyanakkor felmerült az olyan új ismeretek megszerzése iránti igény is, amelyek elsősorban a vállalkozási ismeretekhez kapcsolódtak. A kilencvenes évek felnőttképzésének vezérmotívumává - a korábbi közmüvelődési funkció helyett - az emberi erőforrás fejlesztése és racionálisabb felhasználása vált. S így nem csoda, hogy az ezredfordulón hazánkban is a felnőttképzés müvelődési szolgáltató ágazattá vált. A közmüvelődési intézmények jogi helyzetét 1997-ben jogszabállyal rendezték. Ezt ugyan két alkalommal is módosították az elmúlt három esztendőben (a 2012. évi CLII. törvénnyel és a 2013. évi CCXVII. törvénnyel), ám ezekkel csak kisebb változtatásokat hajtott végre a jogszabály-alkotó a rendszeren. Majd megalkották a felnőttképzésről szóló 2001. évi CI. törvényt is. Magyarország Európai Unióhoz való 2004-es csatlakozását követően az uniós szervek által elfogadott, fent említett dokumentumokhoz kellett igazítani a magyar felnőttoktatás és -képzés szabályozását, illetve részben struktúráját is. Ezeket az alapvető változásokat több lépésben, legutóbb pedig a 2013. évi LXXVII. törvény segítségével próbálták meg a magyar viszonyokra átültetni. Lássuk, milyen sikerrel!

\section{Felnőttoktatás a köznevelési intézményekben}

A 2012/13-as tanévben a magyar köznevelési intézményekben majd 88 ezren tanultak, vagyis 9 ezer fővel kevesebben, mint 2005-ben. Ez 10\%-os csökkenést jelent. 2014/15-re a részvétel 79 ezer tanulóra csökkent, s ez arányaiban már 18\%-os csökkenést jelentett. Az eltérés azonban iskolatípusonként eltérő volt. Míg a felnőttoktatásban tanuló általános iskolások száma alig változott, 2 ezer fő körül mozgott, addig az érettségit adó iskolatípusokban nőtt, illetve 2005 és 2012 között a szakiskolákban a diákok száma megháromszorozódott, majd a 2014/15-ös tanévben 25\%-os visszaesés volt tapasztalható. Az elmúlt tanév során gimnáziumban kicsit több mint 34 ezren, szakközépiskolában alig 33 ezren tanultak.

1. ábra

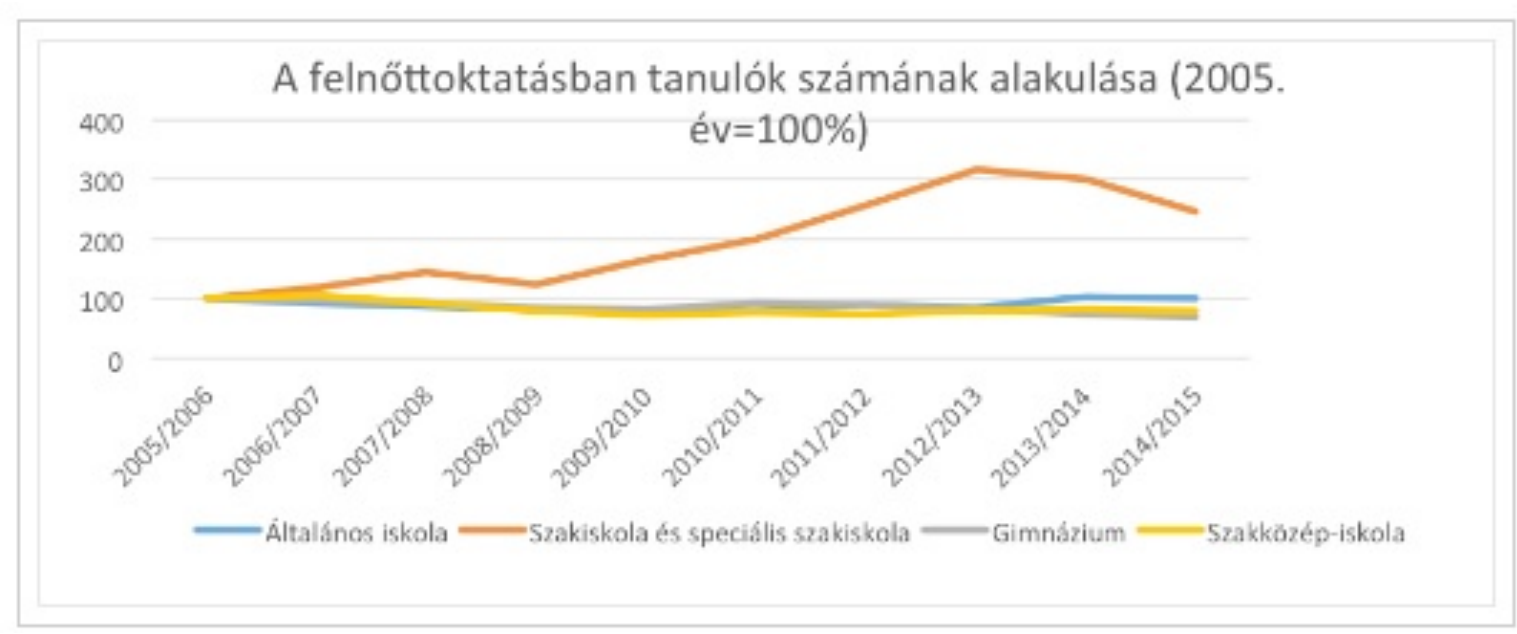

Forrás: www.ksh.hu

A sikeres érettségi vizsgát tevők száma a gimnáziumokban 2005 és 2012 között 10\%-kal növekedett, 2012-ben 7645-en maturáltak. Majd 2014-re ez a szám 6546-ra visszaesett. Mindeközben a szakközépiskolákban érettségizők száma 4,5 ezerről 1,5 ezer körülire 
csökkent. Vagyis úgy tünik, akinek a célja az érettségi megszerzése, inkább a gimnáziumot választja tanulmányai helyéül. Ezen adat tükrében furcsállhatjuk, hogy a középfokú oktatáson belül a gimnáziumok visszaszorításáról szóló híreket hallhatunk.

2. ábra

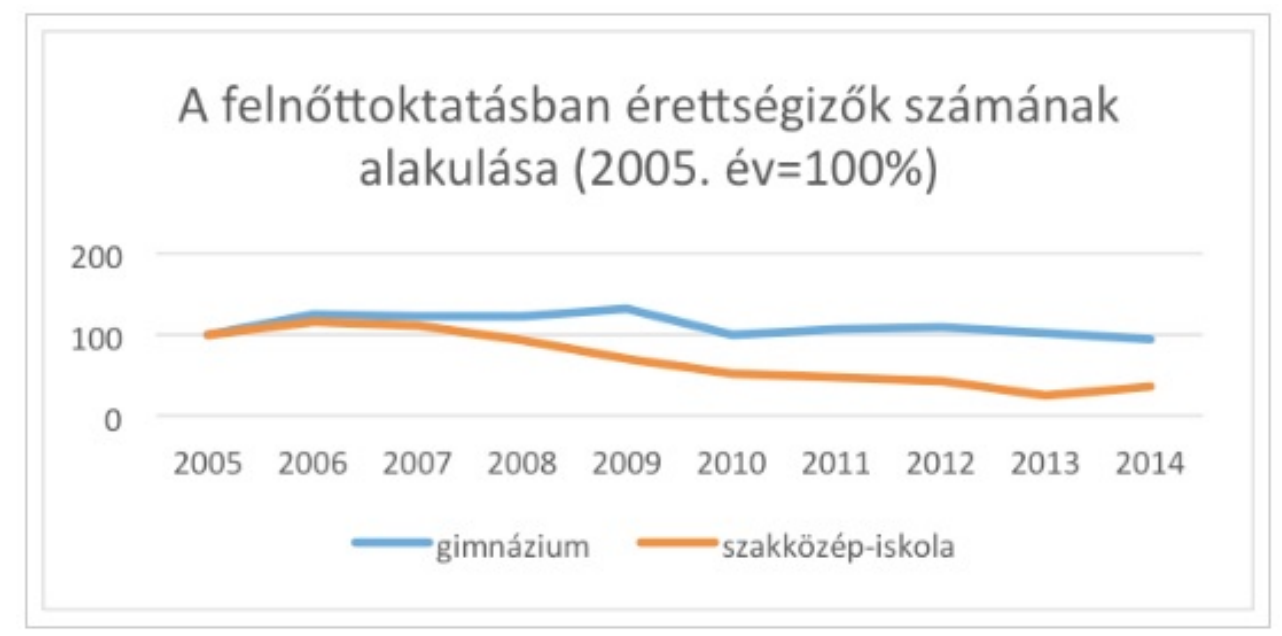

Forrás: www.ksh.hu

\section{Felnőttoktatás a felsőoktatásban}

Tágabb értelemben véve a teljes felsőoktatás a felnőttoktatás területéhez tartozik, hiszen csak a már nagykorú népesség kezdheti meg tanulmányait ezen a szinten. Szűkebben értelmezve azonban a felnőttoktatáshoz a felsőoktatásnak a nem nappali - vagy sokszor részidősnek nevezett - képzései tartoznak, ezek közé soroljuk az esti és a levelező munkarendet, valamint a távoktatást.

Magyarországon a Bolognai Nyilatkozat ${ }^{101}$ aláírásával jelentős átalakulások kezdődtek a felsőoktatásban. Többek között bevezették az egységesen egymásra épülő többciklusú képzési rendszert, ami új szintek, a felsőfokú alap- és mesterképzés, illetve néhány képzési területen (pl. az orvosi vagy jogi szakokon) az osztatlan képzés megjelenését eredményezte.

A már oklevéllel rendelkező hallgatók a magasabb végzettségi szintet nem biztosító szakirányú továbbképzéseken, illetve a $\mathrm{PhD}$ vagy DLA tudományos fokozatmegszerzésére irányuló doktori programokban tanulhatnak tovább. Mindezek mellett lehetőség van az oklevelet nem adó felsőoktatási szakképzésben való részvételre is.

A 2000-es évek közepétől a nem nappali képzés hallgatói létszáma46\%-kal csökkent, míg a nappali képzésben részt vevőké stagnált. Ebből adódóan 2014-re a részidős formákban tanuló hallgatók aránya 16 százalékponttal lett alacsonyabb 2005-höz képest. A nem nappali képzésben résztvevők számának és arányának nagymértékü csökkenése elsősorban abból adódik, hogy a továbbtanulni szándékozó felnőttek többsége már korábban, még annak az időszaknak az első felében folytatta felsőfokú tanulmányait, amikor az egyetemekre, főiskolákra való bekerülés szigorú feltételei némiképp lazultak. Mindezek ellenére a nem nappali képzések változatlanul jelentős súllyal bírnak, hiszen 2014-ben a hallgatók 30\%-a közel 90 ezer fö - választotta a részidős formák valamelyikét.

\footnotetext{
${ }^{101} \mathrm{http} / / / \mathrm{www} . f e l v i . h u / f e l s o o k t a t a s i m u h e l y /$ archivum/bologna/a bolognai nyilatkozat szovege/ (letöltés: 2015. november 27.)
} 
3. ábra

\begin{tabular}{|l|l|l|l|}
\hline \multicolumn{5}{|c|}{ Felsőoktatásban résztvevő hallgatók száma munkarend szerint } \\
\hline Tanév & Nappali képzésben & Nem nappali képzésben & Összesen \\
\hline Száma, fó & \multicolumn{3}{|l|}{} \\
\hline $2005 / 2006$ & 231482 & 192679 & 424161 \\
\hline $2006 / 2007$ & 238674 & 177674 & 416348 \\
\hline $2007 / 2008$ & 242893 & 154811 & 397704 \\
\hline $2008 / 2009$ & 242928 & 138105 & 381033 \\
\hline $2009 / 2010$ & 242701 & 127630 & 370331 \\
\hline $2010 / 2011$ & 240727 & 120620 & 361347 \\
\hline $2011 / 2012$ & 241614 & 118210 & 359824 \\
\hline $2012 / 2013$ & 233678 & 104789 & 338467 \\
\hline $2013 / 2014$ & 223604 & 96520 & 320124 \\
\hline $2014 / 2015$ & 217248 & 89276 & 306524 \\
\hline
\end{tabular}

Forrás: www.ksh.hu

A vizsgált időszakban a nem nappali képzésekre járók körében is a gazdasági szakok voltak a legnépszerübbek. Ezt követi - a 2009/2010-es tanév kivételével - a tanárképzés, amely az egyetlen olyan terület volt, ahol végig a részidős hallgatók voltak többségben. A harmadik helyen sokáig aszolgáltatás képzési terület állt, amit az utóbbi néhány évben a müszaki tudományok váltottak fel, míg ajog ötödikként stabilan tartja pozícióját. A legkevesebb hallgató a müvészeti programokban vett részt.

4. ábra



Forrás: www.ksh.hu 


\section{Hibák a kréta körül}

A felnőttoktatás/felnőttképzés problémái között a szakmai jellegűekhez soroljuk például a kereslet-kínálat eltéréseit. Továbbá azt, hogy a képzési rendszer rugalmatlan, a képzési kínálat módosítása nehézkes. Hogy az intézményrendszer szétaprózott, s így a müködés nem költséghatékony. Hogy elavult szakmai tartalom, magasak az elvárások, túlsúlyban van az elmélet. Hogy gyakorlati oktatás/képzés során gyakran szembesülünk a valós munkatapasztalat hiányával. Hogy a pályaválasztás során a pályaorientáció, a tanácsadás problémás, hiányos a pályakövetés is. Hogy gond van a szakmai vizsga ellenőrzésével, valamint az oktatók (tovább)képzésével. Ám talán ezeknél is nagyobb gondot jelentenek a jogszabályi változások, vagy az oktatáspolitika következetlenségei. Példának okáért, hogy az új szabályok azoknak a vállalkozásoknak a forrásait is apasztják, amelyek eddig a felnőttképzési intézményeknél, vállalkozásoknál vásároltak szolgáltatásokat. Így a felnőttoktatás piaci szereplöi járnak igencsak rosszul.

Kiszorulóban vannak a piaci vállalkozások a munkaügyi központok által meghirdetett tenderekből is. Ezeken egy új szereplő, a Türr István Képző és Kutató Intézet (TKKI) a favorit. A kilencvenes évek elején létrehozott, de később kiürült kilenc regionális képzőközpontot 2011-ben fedezte fel magának a Közigazgatási és Igazságügyi Minisztérium, és az olasz egységért küzdő egykori 48-as szabadságharcosról elnevezett intézet lett a közfoglalkoztatással összefüggő feladatok letéteményese. Az „Újra tanulok” elnevezésű, 2012 áprilisa és 2015 áprilisa között futott, 44 milliárd forintos uniós forrásra eddig csak a TKKI által közfoglalkoztatottaknak felajánlott képzéseket fogadták be, a romatelepek komplex programjára pedig csak azok az önkormányzatok pályázhattak, amelyek konzorciumi partnerként a TKKI-t is bevonták.

A felnőttképzési szakemberek attól is tartanak, hogy az állam ennél is határozottabban ráteszi a kezét a piacukra: áttereli a diákokat az állami fenntartású intézményekbe, így úszva meg a különben feleslegessé váló pedagógusok elbocsátását. Erre több jel is mutat. Például, hogy mind az új köznevelési törvény, mind pedig az új szakképzési törvény a szakközépiskolák (az új szakgimnáziumok) alapfeladatai között sorolja fel a felnőttképzést.

Végül, összegezve a leírtakat: egész életen át tartó tanulás fontosságáról ma már senkit nem kell meggyőzni. Annak szükségességét csaknem mindenki felismerte, ugyanakkor Magyarország az iskolázottsági szint, valamint a felnőttképzés tekintetében is elmarad az EU többi tagállamától, és a felzárkózás nem kellő ütemü. Tagadhatatlan, hogy nem egyedül a pénzhiány következtében kedvezőtlen a helyzet, de mint az az európai stratégiai célkitüzésekben is megfogalmazódott: feltétlenül szükséges, hogy jelentősen növekedjen a humán tőkébe történő egy főre jutó beruházás. E mellett - úgy vélem - a felnőttképzési rendszer átgondolása, és annak egyéni és munkaerö-piaci igényekhez történő igazítása, „finomhangolása” is elengedhetetlen. 